\title{
Papers
}

\section{An evaluation of e-mail marketing and factors affecting response}

Received (in revised form): 25th October, 2002

\section{Lisa Chittenden}

is Director of Data Strategy at Claritas Interactive, which specialises in developing e-marketing strategies targeted at consumers.

\section{Ruth Rettie}

was a Unilever brand manager and is now a senior lecturer in Internet marketing at Kingston University, specialising in new media marketing and communications.

\begin{abstract}
E-mail marketing is increasingly recognised as an effective Internet marketing tool. This paper reviews the e-mail marketing literature which highlights the importance of obtaining recipients' permission. E-mail marketing is compared with other forms of direct and Internet marketing, identifying its key advantages. The factors that have been found to increase response rate in direct marketing and direct mail are identified.

Following exploratory qualitative research among industry experts 30 e-mail marketing campaigns were analysed to identify factors associated with higher response rates; the following factors were found to be associated with increased response rate: subject line, e-mail length, incentive, number of images. For nine of these campaigns it was possible to link demographic and lifestyle data to response. Analysis of these campaigns suggests that recipients who have bought online have higher response rates. These findings are used to create an e-mail marketing process model based on the Vriens et al. direct mail process model. ${ }^{1}$
\end{abstract}

\section{INTRODUCTION}

The advent of the Internet has created a new channel for marketing. It has been described as 'the most important innovation since the development of the printing press' and that it will 'transform not just the way individuals go about conducting their business with each other, but also the very essence of what it means to be a human being in society'. ${ }^{2}$ The transition from the old world of business management to the new world of e-customers is unique.

The effect of this change in the communication chain is altering the way companies market to their customers and prospects and how they deliver their messages and products. The traditional 'make and sell' paradigm uses above the line 'push' marketing tactics. 'Pull' thinking, however, goes beyond the creation of the product and helps in the investigation of every transaction between the organisation and the customer from the customer's point of view. ${ }^{3}$

\section{THE IMPACT OF E-MAIL}

E-mail is the fastest-growing communications technology in history. From only $2 \mathrm{~m}$ e-mail accounts in 1985, this grew to $891.1 \mathrm{~m}$ e-mail accounts at 


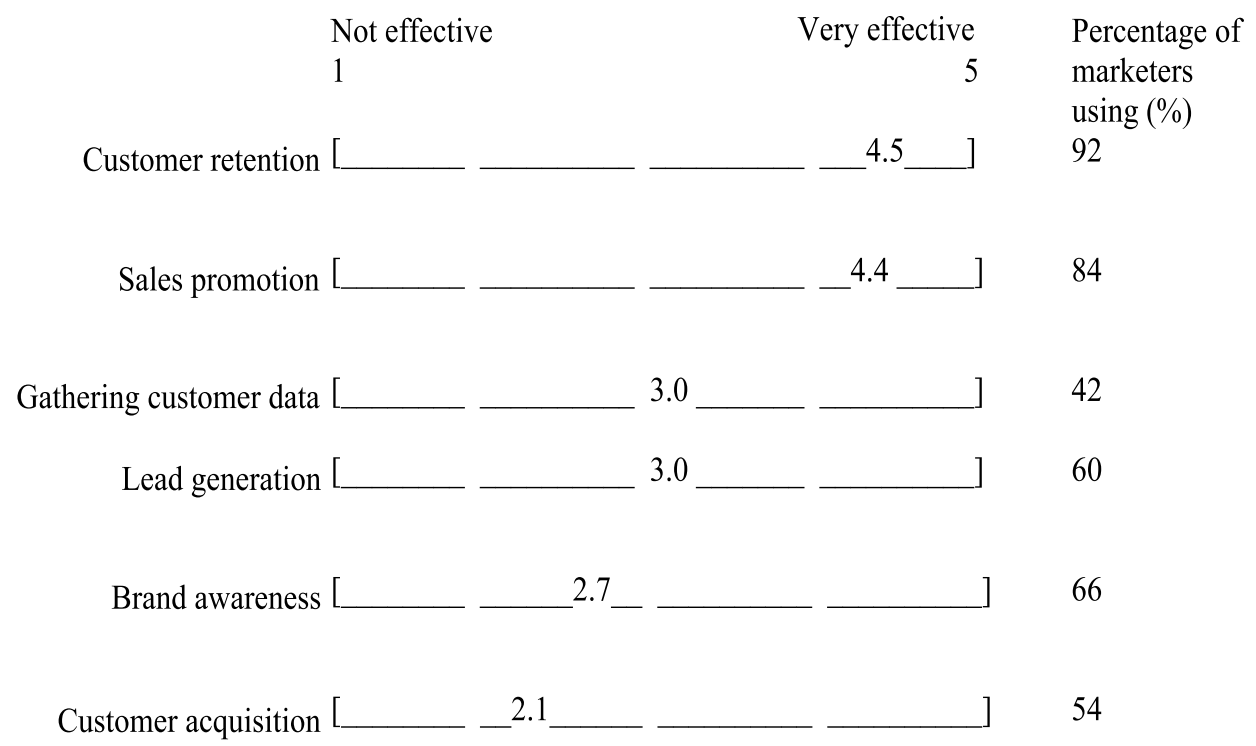

Figure 1 Effectiveness ratings for e-mail as a marketing tool

the beginning of 2001. It was predicted that the global number of e-mail accounts would break the 1 bn barrier during 2002. ${ }^{4}$ E-mail has also changed how, with whom and about what people communicate. It has forced executives to learn to type and grandmothers to sign on to the Internet.

In response to this growing channel of communications, marketers have begun to see that they can replicate offline advertising methods online. Any way to communicate that is easier, cheaper or quicker always has high appeal - the Internet offers all three. This, together with the benefits of one-to-one marketing afforded by e-mail, has brought marketers onto the Internet. They recognise that e-mail provides them with opportunities to establish two-way channels of communication that permit relationship building and real time interaction with customers. There is no doubt that traditional paper-based direct mail is beginning to see increased competition from Internet direct mail, which features the advantages of lower cost, less production, faster delivery and easier response.

\section{ACQUISITION VS RETENTION}

E-mail is becoming a major tool for customer retention due to these speed and cost benefits. A report by Forrester Research in August, 2001, revealed that almost 90 per cent of US e-mail marketing was to existing customers. ${ }^{5}$ Fifty US marketers were interviewed and when asked, 'Do you use e-mail to accomplish the following marketing goals? How effective is it?' the results shown in Figure 1 were found.

Those effectiveness ratings speak for themselves and demonstrate that the main focus of e-mail activity is, indeed, within customer retention. One of the main reasons behind this trend is the stark cost differential between retention and acquisition using e-mail marketing (see Table 1).

The psychology of the Internet also plays an important part. This is where we start to see why consumers begin, in increasing numbers, to rely on the Internet and e-mail marketing as a valuable communication and purchasing vehicle. E-mails are personal, usually requested and, therefore, welcomed. If marketers have a database of individuals 
Table 1: Comparison of costs between direct mail and e-mail for acquisition and retention campaigns ${ }^{6}$

\begin{tabular}{|c|c|c|}
\hline \multicolumn{3}{|c|}{ E-mail for customer acquisition } \\
\hline & Direct mail $£$ & Opt-in e-mail $£$ \\
\hline Design & 5,000 & 5,000 \\
\hline Print & 6,000 & \\
\hline Fulfilment & 7,500 & 750 \\
\hline Postage & 13,000 & \\
\hline List costs & 6,600 & 15,000 \\
\hline Total & 38,100 & 20,750 \\
\hline \multicolumn{3}{|c|}{ E-mail for customer retention } \\
\hline & Direct Mail $£$ & Opt-in e-mail $£$ \\
\hline Design & 5,000 & 5,000 \\
\hline Print & 6,000 & \\
\hline Fulfilment & 7,500 & 750 \\
\hline Postage & 13,000 & - \\
\hline List costs & - & - \\
\hline Total & 31,500 & 5,750 \\
\hline
\end{tabular}

who have opted-in to receiving e-mails from their organisation, then they have access by invitation to a customer communication channel more powerful and less costly than the letterbox that also has none of the intrusive and unwanted connotations of the telephone. Consumers and customers treat their inbox as a personal domain. As long as companies seek permission to send messages, and do not abuse this privilege, they have the ability to build profile, awareness and, ultimately, a profitable relationship with that person.

In addition to the above evidence, there are plenty of published figures that suggest e-mail marketing can deliver a significantly heightened response compared to direct mail. Di Ianni ${ }^{7}$ claims that 'response rates rise from between six and 10 per cent for untargeted e-mails to 17 per cent for targeted e-mails and 32 per cent for individualised communications. ... [E]xperience is that traditional offline direct mail has a response rate of just two or three per cent'. Rosenspan quotes one client as stating: 'we got a two per cent response in two hours and an 11 per cent response within one day'. 8

\section{KEY FACTORS THAT INFLUENCE RESPONSE IN E-MAIL MARKETING}

Given the relative newness of e-mail marketing, coupled with its dramatic rise as an important player in the media mix, the lead author's company has commissioned an analysis into the key factors that influence response.

Thirty live e-mail campaigns were analysed from which a consolidated dataset was derived specifying information about a number of elements including subject line, number of links, response rate, unsubscribe rate, incentive, number of scrolls and imagery. All individuals were opted-in and therefore it was not possible to analyse the importance of permissioning. All campaigns were business to consumer.

\section{ANALYSIS METHODOLOGY}

This study uses two data sets that provide different insights into e-mail marketing responsiveness. The first data set was collated in a spreadsheet by the lead author's company, held against the 30 campaigns that it managed. These data have been used to understand how the style of an e-mail and the list affect responsiveness (measured by clickthrough rates).

The second data set uses ten of the original 30 campaigns to analyse further whether there are any patterns in the demographics and/or lifestyles of individuals who respond to e-mails. The objective of this is to understand if there are any generic characteristics that can 
Table 2: Summary of the top and bottom five responding e-mail campaigns

\begin{tabular}{lll}
\hline Summary & Top $\mathbf{5}$ responding campaigns & Bottom $\mathbf{5}$ responding campaigns \\
\hline Average \% deliver & 82.3 & 84.3 \\
Average \% clickthrough & 12.4 & 0.8 \\
Average \% unsubscribe & 1.8 & 1.8 \\
Average number of scrolls & 1.4 & 2.7 \\
Average number of links & 2.8 & 2.4 \\
Average number of images & 2.0 & 1.2 \\
Incentive & $4 \times$ high value Prize draw and & $1 \times$ Prize draw and \\
Subject line & $1 \times$ Amazon voucher & $4 \times$ product savings \\
Targeting & Detaining value of incentive & Proposing offer of savings \\
& Highly targeted to product & Broader targeting \\
\hline
\end{tabular}

predict whether someone will respond, over and above the creative style of the e-mail.

\section{CREATIVE ANALYSIS METHODOLOGY}

At the outset of this study, it was possible to use the full universe of campaign creatives, thereby providing a full analysis of the results.

The first stage was to develop a spreadsheet of all key information:

- client

- HTML or text

- product type

- volume delivered

- clickthrough rate

— volume and percentage unsubscribe

- incentive type

- subject line

- targeting applied to list

- length of e-mail

- number of clickthrough links

— number of images.

Where possible, the information was input as ordinal data. This information was reviewed to identify any key patterns in the responsiveness (clickthrough rate) of each of the campaigns. The data were then imported into SPSS to produce a correlation analysis of variables: clickthrough rate, unsubscribe rate, length of e-mail, number of links and number of images. The purpose of this analysis was to review whether there are any specific elements of an e-mail creative that affects the clickthrough rate of consumers.

\section{Demographic and lifestage analysis}

The objective of this part of the study was to review if there are any significant demographic elements that affect responsiveness to an e-mail. Delivered and response records of the ten selected campaigns were analysed against demographics: age, income, number of children, occupation, house type and lifestyle variables.

\section{Clickthrough analysis}

The 30 campaign results were sorted in descending order by the percentage of clickthroughs achieved by the campaign. The top and bottom five responding campaigns were identified and their results summarised in Table 2 .

The findings of this initial analysis reveal several factors that seem to affect responsiveness (see Figure 2).

The lowest responding e-mails were nearly twice the length (number of scrolls) of the highest responding group. This suggests that length of e-mail has a 


\section{CLICKTHROUGHS - TOP 5 VS BOTTOM 5 - CREATIVE INFORMATION}

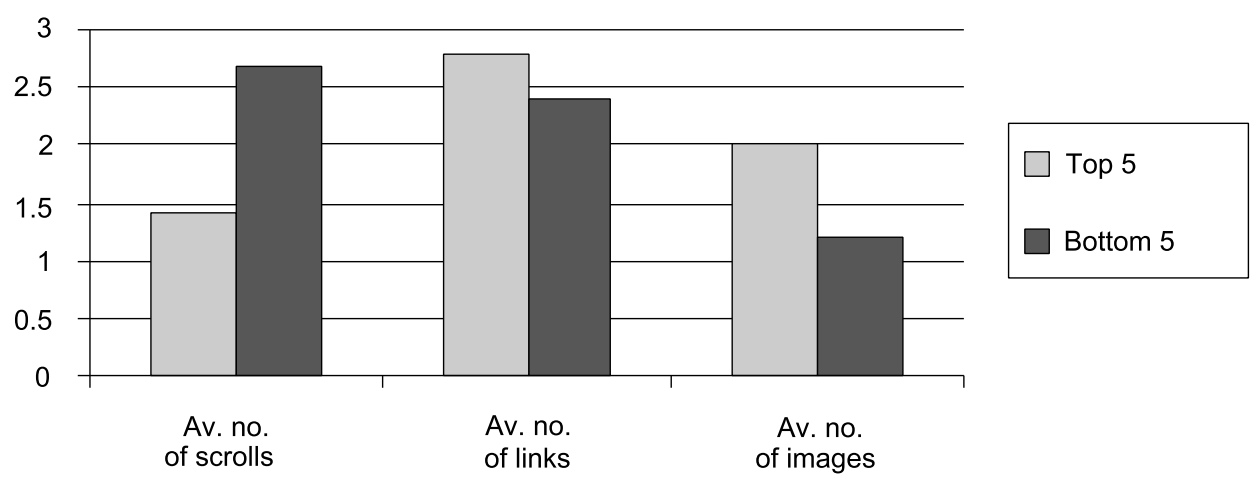

Figure 2 Creative impact on response

CLICKTHROUGHS - TOP 5 VS BOTTOM 5 RESPONSE INFORMATION

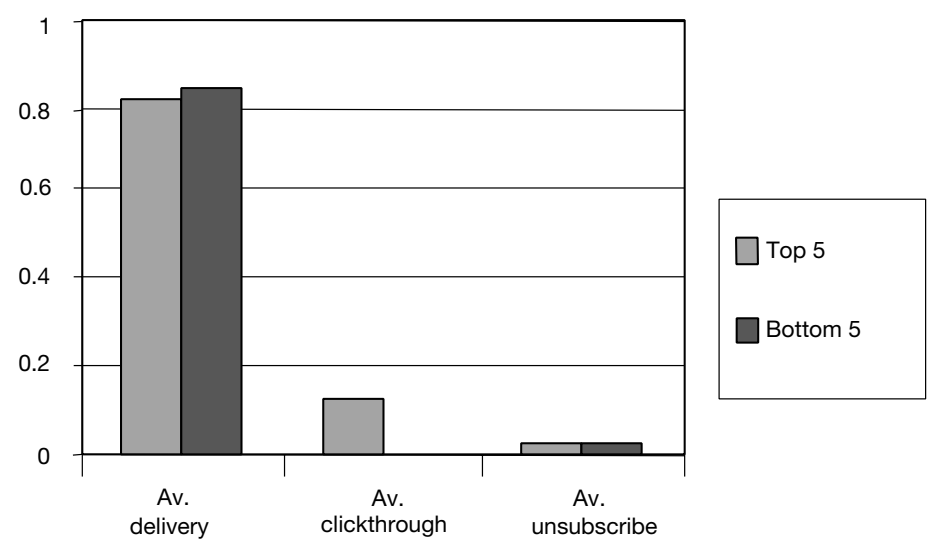

Figure 3 Impact on unsubscribe rates

significant effect. Interestingly, the number of images is less in the lower responding group, suggesting that the more colourful and attractive e-mails generate greater response.

Another significant finding is that the average percentage of unsubscribe is the same between the two groups - thus an e-mail generating a poor response does not necessarily generate a higher unsubscribe rate (see Figure 3).

Godin believes strongly that permission marketing needs to be 'anticipated, personal and relevant'. ${ }^{9}$ The results of the review of targeting, subject line and offer in Table 3 concur with this by revealing that the better the list of individuals targeted for an e-mail, the better the response.

Relevance of the individual's preferences will influence their clickthrough behaviour. Also of interest is that the subject line in the top five used the power and value of the incentive, as opposed to the actual product the e-mail was marketing. The sample is too small to analyse which of these elements is the most significant. It does reveal, however, that a targeted list, together with a strong incentive detailed in the subject line, will improve response rates. 
Table 3: Creative information on the top and bottom five responding e-mails

\begin{tabular}{|c|c|c|c|c|}
\hline HTML/Text & Product & Incentive & Subject line & Selection criteria \\
\hline \multicolumn{5}{|l|}{ Top 5} \\
\hline HTML & Malt whisky & Holiday prize draw & $\begin{array}{l}\text { Exclusive all expenses } \\
\text { paid weekend in Speyside }\end{array}$ & Known malt drinkers \\
\hline Text & Market research & Amazon voucher & $\begin{array}{l}\text { Free Amazon e-voucher } \\
\text { for giving us your opinions }\end{array}$ & Drivers of new cars \\
\hline HTML & Female website & $\begin{array}{l}\text { Melbourne holiday } \\
\text { prize draw }\end{array}$ & $\begin{array}{l}\text { Win a } £ 6,000 \text { holiday } \\
\text { to Melbourne }\end{array}$ & $\begin{array}{l}\text { Female, age } 26-45 \\
\text { interested in health or } \\
\text { travel or culture or } \\
\text { eating out or fashion }\end{array}$ \\
\hline HTML & Search website & $£ 5,000$ prize draw & $\begin{array}{l}\text { Win } £ 5,000 \text { with Yell.com! } \\
\text { (for home improvements) }\end{array}$ & $\begin{array}{l}\text { Homeowners } \\
\text { interested in DIY }\end{array}$ \\
\hline HTML & Fashion & $\begin{array}{l}\text { Milan weekend } \\
\text { prize draw }\end{array}$ & Luxlook Milan competition & $\begin{array}{l}\text { Female, income } £ 30 \mathrm{k}+ \\
\text { interested in fashion }\end{array}$ \\
\hline \multicolumn{5}{|r|}{ milerested int rastilum } \\
\hline Text & Computers & Summer offers & $\begin{array}{l}\text { Summer savings on IBM } \\
\text { NetVista PCs - direct } \\
\text { from IBM }\end{array}$ & $\begin{array}{l}\text { Income } £ 30 \mathrm{k}+\text {, aged } \\
30+\text {, professional }\end{array}$ \\
\hline HTML & Dental care & $25 \%$ off dental care & $\begin{array}{l}25 \% \text { off at Boots } \\
\text { Dentalcare }\end{array}$ & $\begin{array}{l}\text { Geographic range } \\
\text { around stores }\end{array}$ \\
\hline HTML & Gas/Electricity & Web traffic drive & $\begin{array}{l}\text { In ten minutes you could } \\
\text { start saving } £ 150 \text { off your } \\
\text { bills }\end{array}$ & $\begin{array}{l}\text { Aged } 25-35 \\
\text { homeowners }\end{array}$ \\
\hline HTML & $\begin{array}{l}\text { Sunday Times/ } \\
\text { Golf offer }\end{array}$ & Holiday prize draw & $\begin{array}{l}\text { Play Your Way to } \\
\text { South Africa }\end{array}$ & Interested in golf \\
\hline HTML & $\begin{array}{l}\text { Online shares/ } \\
\text { investments }\end{array}$ & $\begin{array}{l}30 \text { days' free } \\
\text { commission }\end{array}$ & $\begin{array}{l}\text { Are you interested in } \\
\text { making more money? }\end{array}$ & $\begin{array}{l}\text { Age } 30+\text {, professional, } \\
\text { interested in stocks } \\
\text { and shares }\end{array}$ \\
\hline
\end{tabular}

\section{Unsubscribe analysis}

It was also considered important to review the factors affecting the unsubscribe rate. Permission marketing requires the e-mail sender to incorporate a facility for consumers to unsubscribe from their list. ${ }^{10}$ If consumers receive e-mails they do not like and unsubscribe, then the cost to the list owner is high. They can no longer communicate with that individual, thus reducing their ability to market to them in any e-mail capacity, whether it is useful product information or new product marketing. If there are any key elements that increase the likelihood an individual will unsubscribe, then this can be incorporated into e-mail design.

The full data set of 30 campaigns was sorted descending by unsubscribe percentage. Details of the campaigns with the top five (highest) and bottom five (lowest) rates of unsubscribe are shown in Tables 4 and 5 .
The length of the e-mail (number of scrolls) again seems to be relevant to the percentage of people who unsubscribe the longer the e-mail, the higher the likelihood of a customer unsubscribing (see Figure 4).

The percentage of unsubscribes increases as the number of links reduces. This may relate to the fact that the unsubscribe is the last link on the e-mail, so the consumer may be more aware of this option when there are fewer links to divert attention.

There appears to be some relationship between the response rate and the unsubscribe rate, which is different from the clickthrough analysis which suggested there was no relationship. The high unsubscribes have a lower response rate than the low unsubscribes (see Figure 5).

When comparing this analysis to the clickthrough analysis, it can be seen that a similar pattern in respect of the incentive, subject line and targeting affect the level 
Table 4: Summary of the top and bottom five unsubscribe rate analysis

\begin{tabular}{|c|c|c|}
\hline Summary & Top 5 responding campaigns & Bottom 5 responding campaigns \\
\hline Average $\%$ deliver & 78.3 & 87.0 \\
\hline Average \% clickthrough & 4.1 & 7.1 \\
\hline Average \% unsubscribe & 3.9 & 0.2 \\
\hline Average number of scrolls & 2.0 & 1.5 \\
\hline Average number of links & 2.8 & 3.8 \\
\hline Average number of images & 1.6 & 1.2 \\
\hline Incentive & $\begin{array}{l}1 \times \text { prize draw, } 2 \times \text { information } \\
\text { only, } 2 \times \text { product offer }\end{array}$ & $\begin{array}{l}3 \times \text { prize draw, } 1 \times \text { Amazon voucher, } \\
1 \times \text { cash back }\end{array}$ \\
\hline Subject line & Detailing value of incentive & Proposing offer of savings or \\
\hline Targeting & $\begin{array}{l}\text { Highly targeted to product } \\
\text { and incentive }\end{array}$ & $\begin{array}{l}\text { information about product } \\
\text { Quite targeted to product }\end{array}$ \\
\hline
\end{tabular}

UNSUBSCRIBES - TOP 5 VS BOTTOM 5 CREATIVE INFORMATION

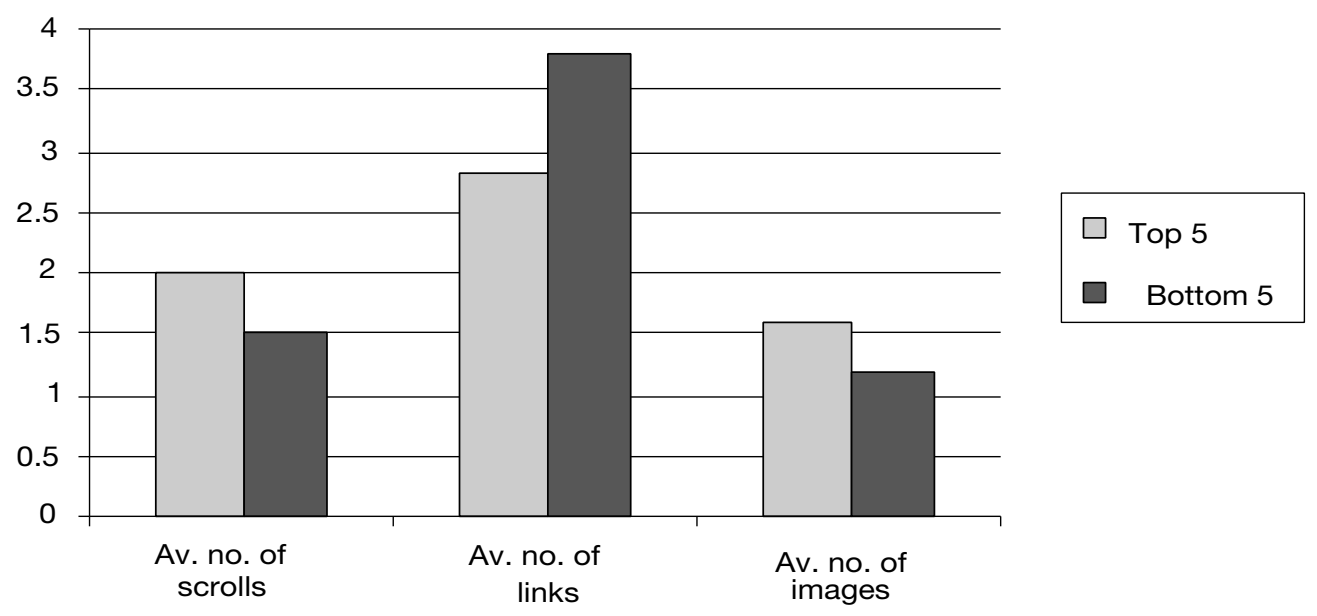

Figure 4 Creative impact on response, ranked by unsubscribe rate UNSUBSCRIBES - TOP 5 VS BOTTOM 5 -
RESPONSE INFORMATION

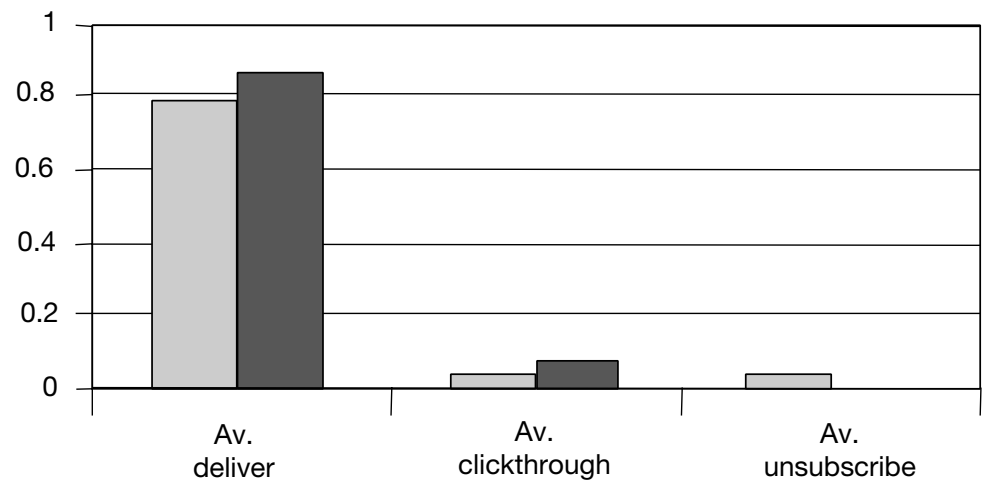

Top 5

Bottom 5

Figure 5 Impact on response ranked by unsubscribe rate 
Table 5: Creative information of top and bottom five unsubscribe e-mails

\begin{tabular}{|c|c|c|c|c|}
\hline HTML/Text & Product & Incentive & Subject line & Selection criteria \\
\hline $\begin{array}{l}\text { Top } 5 \\
\text { HTML }\end{array}$ & Malt whisky & Holiday prize draw & Cool Event & $\begin{array}{l}\text { Age } 35+\text {, interest in } \\
\text { golf }\end{array}$ \\
\hline HTML & Fashion & $\begin{array}{l}\text { Milan weekend } \\
\text { prize draw }\end{array}$ & Luxlook Milan competition & $\begin{array}{l}\text { Female, income } £ 30 \mathrm{k}+ \\
\text { interested in fashion }\end{array}$ \\
\hline HTML & Dental care & $25 \%$ off dental care & $\begin{array}{l}25 \% \text { off at Boots } \\
\text { Dentalcare }\end{array}$ & $\begin{array}{l}\text { Geographic range } \\
\text { around stores }\end{array}$ \\
\hline Text & $\begin{array}{l}\text { Education } \\
\text { services }\end{array}$ & Information & $\begin{array}{l}\text { IT training in two } \\
\text { easy steps }\end{array}$ & $\begin{array}{l}\text { Interest in personal } \\
\text { computing }\end{array}$ \\
\hline HTML & Museum & Free kids entry & $\begin{array}{l}\text { Easter Offer - Kids } \\
\text { and Over } 60 \text { s go free } \\
\text { to the Royal Armouries }\end{array}$ & $\begin{array}{l}\text { Geographic range } \\
\text { around museum and } \\
\text { have kids aged } 0-18\end{array}$ \\
\hline $\begin{array}{l}\text { Bottom } 5 \\
\text { HTML }\end{array}$ & $\begin{array}{l}\text { Sunday Times/ } \\
\text { Golf offer }\end{array}$ & Holiday prize draw & $\begin{array}{l}\text { Play Your Way to } \\
\text { South Africa }\end{array}$ & Interested in golf \\
\hline HTML & Car Insurance & $\begin{array}{l}\text { Peugeot } 106 \text { prize } \\
\text { draw }\end{array}$ & Win a Peugeot 106 & $\begin{array}{l}\text { Age 25-55, renewal } \\
\text { month = August }\end{array}$ \\
\hline HTML & Car purchase & $£ 250$ cash back & $\begin{array}{l}\text { Don't delete this e-mail - } \\
\text { it could be worth £250! }\end{array}$ & $\begin{array}{l}\text { Intend to replace main } \\
\text { car in six months }\end{array}$ \\
\hline Text & Market research & Amazon voucher & $\begin{array}{l}\text { Free Amazon e-voucher for } \\
\text { giving us your opinions }\end{array}$ & Drivers of new cars \\
\hline HTML & Search website & $£ 5,000$ prize draw & $\begin{array}{l}\text { Win } £ 5,000 \text { with Yell.com! } \\
\text { (for home improvements) }\end{array}$ & $\begin{array}{l}\text { Homeowners } \\
\text { interested in DIY }\end{array}$ \\
\hline
\end{tabular}

of unsubscribes. A better-targeted list with a good incentive and subject line will produce fewer unsubscribes.

\section{Defining an accurate SPSS data set}

In order to gain a greater understanding of any relationships between the variables, the ordinal variables from the data set were put into a correlation analysis. Before presenting the data to these analyses, descriptive analysis was carried out on the dependent variable CLICKPER (percentage of clickthrough) to identify any potential outliers and skews. As a result, three records were excluded from the correlation analysis to provide a standard deviation and normal distribution.

\section{CORRELATION ANALYSIS}

Table 6 shows the results of the Pearson Correlation Analysis on the remaining 27 records. The correlation analysis is specifically reviewing which variables correlate to:

1 CLICKPER: clickthrough percentage

2 UNSUBP: unsubscribe percentage.

The matrix in Table 6 shows how the variables interrelate. Although there are no variables that are very close to 1.0 (which would indicate full correlation) the analysis highlights that a number of links and images are positively correlated (bold figures) to clickthroughs, compared to length of e-mail (scrolls) which are negatively correlated. In addition, the length of e-mail is also positively correlated to percentage of unsubscribes (italic figures).

These results back up the findings from the spreadsheet analysis and highlight the importance of the creative feel of the e-mail. It is clear that the length of the e-mail is highly influential in the responsiveness of the consumer. Longer e-mails generate 
Table 6: Summary results of the Pearson Correlation Analysis

\begin{tabular}{|c|c|c|c|c|c|c|}
\hline & & $\begin{array}{l}\text { Correlation } \\
\text { CLICKPER }\end{array}$ & UNSUBP & SCROLLS & LINKS & IMAG \\
\hline \multirow[t]{3}{*}{ CLICKPER } & Pearson Correlation & 1.000 & 0.115 & $-0.474^{*}$ & $0.421^{*}$ & $0.537^{\star \star}$ \\
\hline & Sig. (2-tailed) & 0.000 & 0.584 & 0.012 & 0.029 & 0.004 \\
\hline & $\mathrm{N}$ & 27 & 25 & 27 & 27 & 27 \\
\hline \multirow[t]{3}{*}{ UNSUBP } & Pearson Correlation & 0.115 & 1.000 & 0.256 & -0.076 & -0.035 \\
\hline & Sig. (2-tailed) & 0.584 & 0.000 & 0.217 & 0.719 & 0.869 \\
\hline & $\mathrm{N}$ & 25 & 25 & 25 & 25 & 25 \\
\hline \multirow[t]{2}{*}{ SCROLLS } & Pearson Correlation & $-0.474^{*}$ & 0.256 & $\begin{array}{l}1.000 \\
0.000\end{array}$ & $\begin{array}{r}-0.080 \\
0.691\end{array}$ & 0.046 \\
\hline & $\mathrm{N}$ & 27 & 25 & 27 & 27 & 27 \\
\hline \multirow[t]{3}{*}{ LINKS } & Pearson Correlation & $0.421^{*}$ & -0.076 & -0.080 & 1.000 & 0.305 \\
\hline & Sig. (2-tailed) & 0.029 & 0.719 & 0.691 & 0.000 & 0.122 \\
\hline & $\mathrm{N}$ & 27 & 25 & 27 & 27 & 27 \\
\hline \multirow[t]{3}{*}{ IMAG } & Pearson Correlation & $0.537^{\star \star}$ & -0.035 & 0.046 & 0.305 & 1.000 \\
\hline & Sig. (2-tailed) & 0.004 & 0.869 & 0.822 & 0.122 & 0.000 \\
\hline & $\mathrm{N}$ & 27 & 25 & 27 & 27 & 27 \\
\hline
\end{tabular}

* Correlation is significant at the 0.05 level (2-tailed)

** Correlation is significant at the 0.01 level (2-tailed)

lower response and encourage higher unsubscribe rates.

This poses greater challenges to the e-mail marketing creative designer, especially if they have historically worked in the direct marketing industry where there was the space of an A4 sheet of paper to fill. The findings are clear e-mail messages must be clear, concise and no more than one scroll of the screen.

\section{LIST PROFILE ANALYSIS}

The objective of this part of the study was to review the demographic and lifestyle attributes of respondents (clickthroughs) compared to the universes mailed. Two main studies were produced:

- a review of respondents $v s$ mailed by demographic and lifestyle attributes assigned to them from information held by the lead author's company

- regression analysis of the respondents to review key attributes for predicting response.

For this part of the study, only nine of the original 30 campaigns could be used to provide accurate data (as detailed in the methodology). Table 7 details the nine campaigns used.

These campaigns represent a fairly random spread of product types, responsiveness and targeting, thus providing a good sample of campaigns for this purpose.

\section{DEMOGRAPHIC \& LIFESTYLE REVIEW}

This review is split into four phases of analysis using 16 attributes:

- gender

- marital status

- number of children

- occupation

- home ownership

- age

- lifestage

- income

- bingo

- eating out

— fishing

- foreign travel

- quality news readership

- mid-market news readership 
Table 7: Campaigns used for demographic analysis

\begin{tabular}{|c|c|c|c|c|c|c|}
\hline Campaign & Product & $\%$ clicks & $\%$ unsubs & Incentive & Subject line & Selection criteria \\
\hline Campaign 1 & $\begin{array}{l}\text { Home } \\
\text { moving }\end{array}$ & 4.65 & 2.10 & $\begin{array}{l}\text { Fridge prize } \\
\text { draw }\end{array}$ & $\begin{array}{l}\text { Win a Smeg } \\
\text { fridge/freezer } \\
\text { with asserta } \\
\text { homes }\end{array}$ & $\begin{array}{l}\text { Income } £ 15 \mathrm{k}+\text {, } \\
\text { homeowners, } \\
\text { employed, looking to } \\
\text { move in next } 12 \\
\text { months }\end{array}$ \\
\hline Campaign 2 & $\begin{array}{l}\text { Non-alcoholic } \\
\text { drink }\end{array}$ & 3.86 & 2.57 & $\begin{array}{l}\text { Web traffic } \\
\text { drive }\end{array}$ & $\begin{array}{l}\text { Calling all } \\
\text { parents }\end{array}$ & $\begin{array}{l}\text { Female with kids aged } \\
5-10\end{array}$ \\
\hline Campaign 3 & Mobile phone & 2.96 & 3.26 & Free phone & $\begin{array}{l}\star \star \star \star \star \star \star \\
\text { FREE of Totally } \\
\text { charge }\end{array}$ & $\begin{array}{l}\text { Use of regression } \\
\text { scorecard to top } 20 \%\end{array}$ \\
\hline Campaign 4 & $\begin{array}{l}\text { Online shares/ } \\
\text { investments }\end{array}$ & 0.42 & 1.67 & $\begin{array}{l}30 \text { days free } \\
\text { commission }\end{array}$ & $\begin{array}{l}\text { Are you } \\
\text { interested in } \\
\text { making more } \\
\text { money? }\end{array}$ & $\begin{array}{l}\text { Age } 30+\text {, professional, } \\
\text { interested in stocks } \\
\text { and shares }\end{array}$ \\
\hline Campaign 5 & Wine at retailer & 4.48 & 1.35 & Prize draw & $\begin{array}{l}\text { Retailer brings } \\
\text { you the wines } \\
\text { of the world }\end{array}$ & $\begin{array}{l}\text { Geographic range } \\
\text { around stores }\end{array}$ \\
\hline Campaign 6 & $\begin{array}{l}\text { Home } \\
\text { Insurance }\end{array}$ & 2.52 & 1.70 & $10 \%$ discount & $\begin{array}{l}10 \% \text { discount } \\
\text { on home } \\
\text { insurance }\end{array}$ & $\begin{array}{l}\text { Age } 20-55 \text {, renewal } \\
\text { month = August }\end{array}$ \\
\hline Campaign 7 & $\begin{array}{l}\text { Sunday Times/ } \\
\text { Golf Offer }\end{array}$ & 0.65 & 1.11 & $\begin{array}{l}\text { Holiday prize } \\
\text { draw }\end{array}$ & $\begin{array}{l}\text { Play Your Way } \\
\text { to South Africa }\end{array}$ & Interested in golf \\
\hline Campaign 8 & $\begin{array}{l}\text { Female } \\
\text { website }\end{array}$ & 9.87 & 3.53 & $\begin{array}{l}\text { Melbourne } \\
\text { holiday prize } \\
\text { draw }\end{array}$ & $\begin{array}{l}\text { Win a } £ 6,000 \\
\text { holiday to } \\
\text { Melbourne }\end{array}$ & $\begin{array}{l}\text { Female, age } 26-45 \\
\text { interested in health or } \\
\text { travel or culture or } \\
\text { eating out or fashion }\end{array}$ \\
\hline Campaign 9 & $\begin{array}{l}\text { Search } \\
\text { website }\end{array}$ & 8.22 & 0 & $\begin{array}{l}£ 5,000 \text { prize } \\
\text { draw }\end{array}$ & $\begin{array}{l}\text { Win } £ 5,000 \\
\text { with Yell.com! } \\
\text { (for home } \\
\text { improvements) }\end{array}$ & $\begin{array}{l}\text { Homeowners } \\
\text { interested in DIY }\end{array}$ \\
\hline
\end{tabular}

- popular news readership

- buy products online.

The four phases are:

- a review of distribution of each variable comparing respondents to mailed

- building an index of the difference between respondents and mailed records. This has been included to build a consistent measurement to compare each of the nine campaigns. It is understood that the profile of each file is skewed by the original targeting applied to the data selected for the campaign. An index normalises this effect by measuring the difference between the distributions of each of the attributes in the two universes
- a summarised report of all the indices against each attribute

- a summary of the positive and negative attributes is produced to detail response indicators.

Godin states that relevance is a key element in encouraging clickthroughs. ${ }^{11}$ Indeed, earlier analysis has revealed how a more highly-targeted list will help increase responsiveness to a campaign.

This analysis aims to look beyond the effects of the initial targeting of a list, to identify if there are any other profile characteristics that affect someone's likelihood to respond.

When summarising all the indices from each of the nine campaigns, initial findings show there are some characteristics that are more (or less) likely to be common among respondents. 

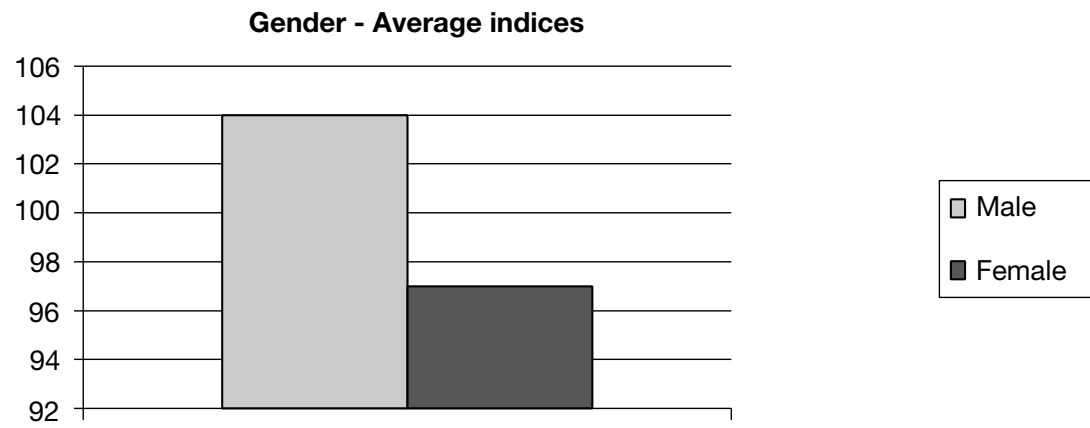

Figure 6 Average indices across the campaigns for gender

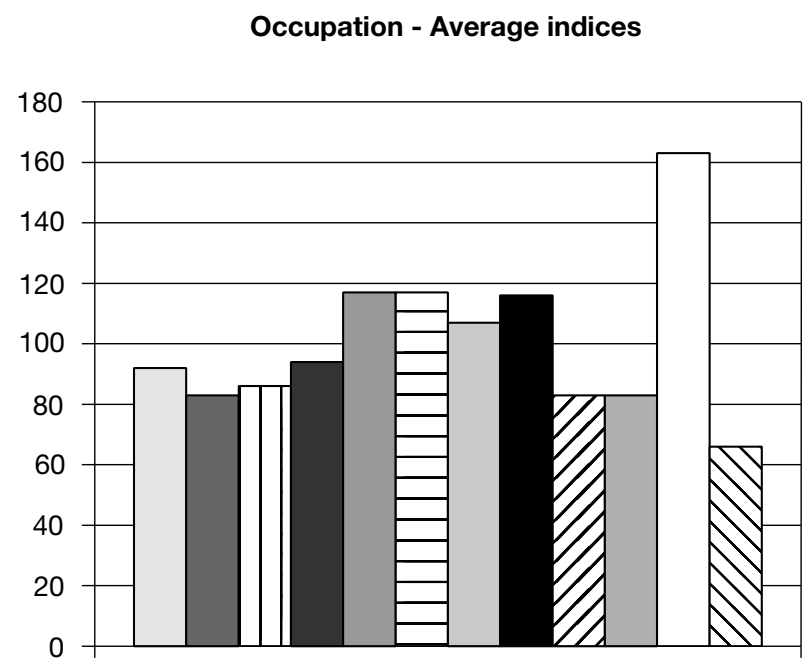

$\square$ Craftsman/Tradesman
$\square$ Education/Medical
$\square$ Housewife
$\square$ Manual/Factory
$\square$ Middle management
$\boxminus$ Office/Clerical
$\square$ Professional/Senior
management
$\square$ Retired
$\square$ Shopworker
$\square$ Student
$\square$ Other
$\square$ Unknown

Figure 7 Average indices across the campaigns for occupation

Presentation of these findings as histograms shows the differences anything above the line of 100 is positive, anything below the line of 100 is negative. It should be noted that indices are really significant over 120 and under 80 - anything between 81 and 119 is indicative only.

Gender shows a slight tendency to be more male (104) than female (97), although this is not highly significant (see Figure 6).

In respect of marital status, single/never married shows a higher likelihood for response than living with parents. This begins to show one of the profile types of respondents, ie young professional individuals, who are potentially more comfortable online and are possibly more e-mail savvy than other elements of society. This is further supported when reviewing occupation, where managerial and office-based occupations show a higher likelihood of response (see Figure 7).

Age shows peaks of high response between 30 and 40 (see Figure 8). Surprisingly, one of the lowest indices of 


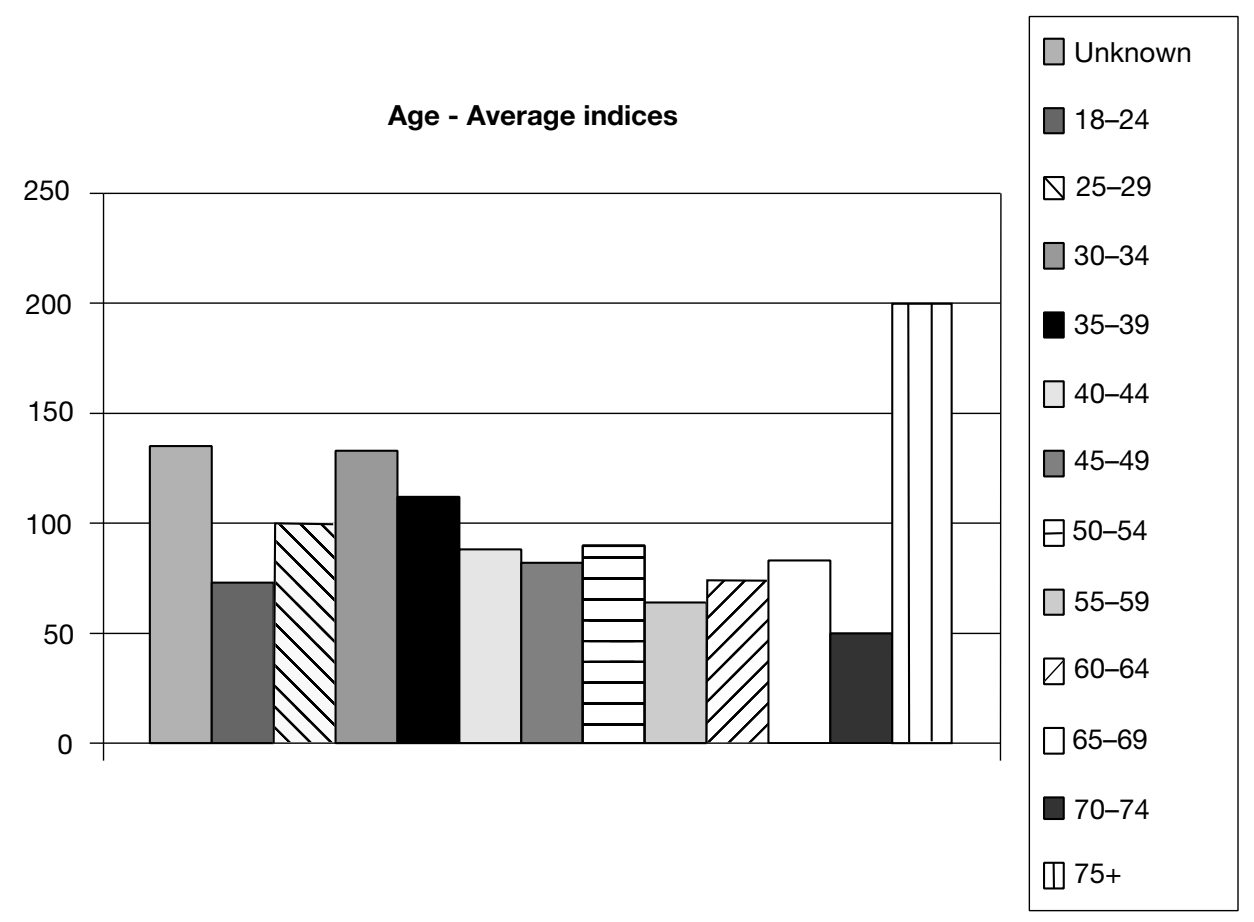

Figure 8 Average indices across the campaigns for age

73 is found within the $18-24$ category. Further analysis within specific age groups would be necessary to understand this fully. It could be, however, that this is more related to lifestage factors than responsiveness itself. The campaigns within this study are reliant on the recipient having disposable income, which is known to be lower within this age group.

Income shows a number of peaks and troughs (see Figure 9). It is, however, worth noting that the lower incomes are negative for response (under $£ 5,000$ has an index of 86 and $£ 5,000-£, 9,999$ of 79), suggesting affluence and/or disposable income are important for responsiveness.

While there is no major significant pattern for either quality newspaper or mid-market newspaper readers, more downmarket popular newspaper readers show a greater likelihood to respond less, with a lowest index of 90 (see Figure 10).
Finally, the last variable in the analysis has proved to be the most important. The fact that someone has previously purchased online was a high indicator for all campaigns (see Figure 11). With the highest index at 174, this suggests that, while demographic and lifestyle factors have a major relevance for responsiveness, ultimately, it is someone's online behaviour and how Web savvy/Web experienced they are that will have most impact on a campaign's success.

The results above have been summarised further in Tables 8 and 9 by identifying the number of positive indices and negative indices against each attribute and then defining them as 'positive' or 'negative' influencers.

This further reveals that younger, professional individuals with high incomes/disposable incomes, upmarket hobbies/newspaper readership who are comfortable purchasing online are the generalised profile of good e-mail 


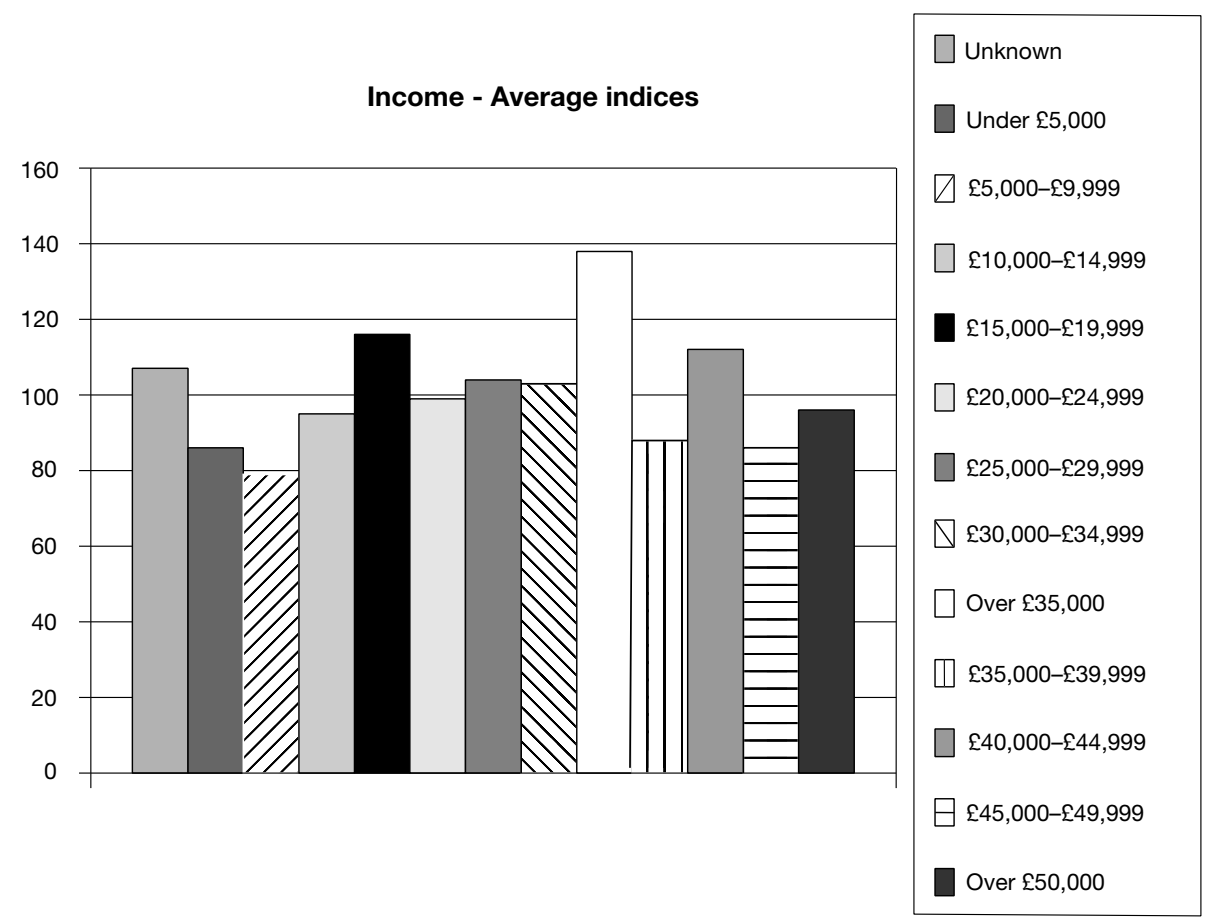

Figure 9 Average indices across the campaigns for income

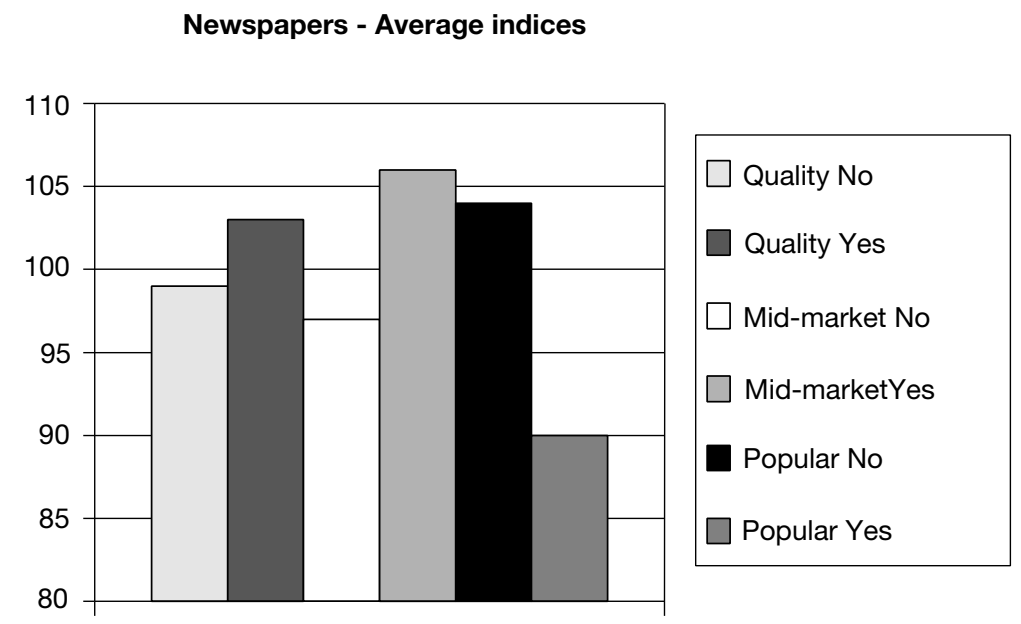

Figure 10 Average indices across the campaigns for newspaper readership

respondents. The negative attributes reveal younger or older people and more practical occupations, with downmarket hobbies and popular newspaper readership, who are less comfortable being online are less likely to be respondents.

\section{CONCLUSIONS}

This qualitative research suggests that e-mail marketing is growing rapidly and should be integrated into the overall communication mix. Interviewees also believed that e-mail marketing would be more effective as a retention rather than 


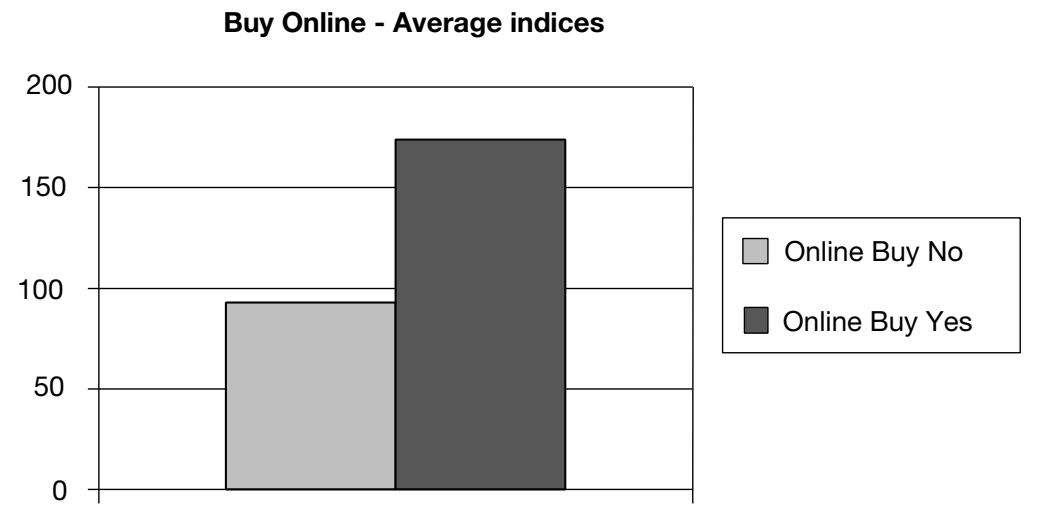

Figure 11 Average indices across the campaigns for having purchased online in the past

Table 8: Positive influencers for e-mail respondents

\begin{tabular}{ll}
\hline Variable description & Answer description \\
\hline POSITIVE ATTRIBUTES & \\
Gender - you & Male \\
Marital status & Single/Never married \\
Number of children at home (0-21 years) & None \\
Occupation - you & Middle management \\
Occupation - you & Office/Clerical \\
Occupation - you & Professional/Senior management \\
Home ownership status & Living with parents \\
Banded age & $30-34$ \\
Banded age & $35-39$ \\
Lifestage & $25-34$, Single, No children under 16 \\
Lifestage & $35-54$, Child $0-4$ \\
Annual household income & $£ 20,000-£ 24,999$ \\
Annual household income & Over £35,000 \\
Annual household income & $£ 40,000-£ 44,999$ \\
Eating out & Yes \\
Foreign travel & Yes \\
Quality newspaper readers & Yes \\
Popular newspaper readers & No \\
Bought online any category & Yes \\
\hline
\end{tabular}

as an acquisition tool, because its interactivity facilitates two-way communication. The experts interviewed also stressed the importance of targeting and the use of 'permissioned' lists. As the latter varies from 'double opt in' company-specific lists to pooled 'opt out' lists, it is likely that the specificity and intensity of permission will also affect response rate.

The response process model suggests that there are three stages in effective e-mail marketing: getting the recipient to open the e-mail, holding their interest and persuading them to respond, hence response rate should depend on the e-mail header as shown in the in-box, the e-mail contents and the recipient. The quantitative research supports this model, with a significant correlation between response rate and subject line, e-mail length, incentive and number of images. Regression on e-mail length and number of images accounted for 54 per 
Table 9: Negative influencers for e-mail respondents

\begin{tabular}{ll}
\hline Variable description & Answer description \\
\hline NEGATIVE ATTRIBUTES & \\
Gender - you & Female \\
Marital status & Living with parents \\
Number of children at home (0-21 years) & 1 \\
Number of children at home (0-21 years) & 2 \\
Number of children at home (0-21 years) & 3 \\
Number of children at home (0-21 years) & $4+$ \\
Occupation - you & Craftsman/Tradesman \\
Occupation - you & Education/Medical \\
Occupation - you & Housewife \\
Home ownership status & Council renters \\
Banded age & $18-24$ \\
Banded age & $25-29$ \\
Banded age & $45-49$ \\
Banded age & $50-54$ \\
Banded age & $55-59$ \\
Lifestage & $18-24$ \\
Lifestage & $35-54$, youngest child 11-16 \\
Annual household income & $£ 35,000-£ 39,999$ \\
Annual household income & $£ 45,000-£ 49,999$ \\
Annual household income & Over £50,000 \\
Eating out & No \\
Fishing & Yes \\
Foreign travel & No \\
Quality newspaper readers & No \\
Popular newspaper readers & Yes \\
Bought online any category & No \\
\hline
\end{tabular}

cent of the variance in response rate.

Analysis of demographic and lifestyle data for nine campaigns found a higher response for respondents who had bought online, who were aged $30-34$ or who had incomes over $f^{35,000}$. These may relate to length of Internet use and early Internet demographics, but unfortunately it was not possible to test this. While this would augur well for the industry as e-mail marketing response rate would increase with length of Internet use, the dramatic growth in 'non-permissioned' e-mail marketing or spam may undermine the development of acquisition e-mail marketing.

\section{References}

1 Vriens, M., van der Scheer, H. R., Hoekstra, J. C. and Bult, J. R. (1998) 'Conjoint experiments for direct mail response optimisation', European Journal of Marketing, Vol. 32, No. 3, pp. 323-339.
2 Hoffman, D. L. (2000) 'The revolution will not be televised: Introduction to the special issue on marketing science and the Internet', Marketing Science, Vol. 19, No. 1, pp. 1-3.

3 Seddon, J. (2000) 'From "push" to "pull" Changing the paradigm for customer relationship management', Journal of Interactive Marketing, Vol 2, No. 1 , pp. $19-28$

4 Messaging Online (2000) 'Year End 2000 Mailbox Report', www.messagingonline.com, accessed on 24th March, 2001.

5 Forrester (2001) 'Surviving the privacy revolution', www.forrester.com, accessed on 29th March, 2001.

6 Source: Claritas. Figures are based on reaching 60,000 individuals taking standard ratecard CPM prices for data from Claritas.

7 Di Ianni, A. (2000) 'The e-business enterprise and the "Web first" principle of e-marketing', Journal of Interactive Marketing, Vol. 2, No. 2, pp. 158-170.

8 Rosenspan, A. (2000) 'Permission is not enough', Journal of Interactive Marketing, Vol. 2, No. 3, pp. 215-218.

9 Godin, S. (1999) 'Permission marketing', Simon \& Schuster, New York.

10 Roberts, S., Feit, M. and Bly, R. W. (2001) 'Internet direct mail', NTC Business Books, Chicago.

11 Godin (1999) op. cit. 